I thank Mr A. E. Covington for suggestions for the work and manuscript.

Radio and Electrical Engineering Division,

D. BASU*

National Research Council,

Ottawa.

Received November 12, 1968; revised February 5, 1969.

* On leave from the Institute of Radio Physics and Electronics, University of Calcutta.

${ }^{1}$ Graf, E. R., Smith, C. E., and McDevitt, F. R., Nature, 218, 857 (1968).

${ }^{2}$ Argyle, E., Nature, 219, 474 (1968).

${ }^{3}$ Solberg, H. G., and Chapman, C. R., Nature, 221, 352 (1969).

+ Scott Smith, T., Nature, 219, 357 (1968).

${ }^{5}$ Croxton, F. E., and Cowden, D. J., in Applied General Statistics, 680 (Prentice Hall, Inc., New York, 1947)

' Peek, B. M., in The Planet Jupiter, 240 (Faber and Fabcr, London, 1958).

\section{Undeformed Sediments in Oceanic Trenches with Sea Floor Spreading}

THE study of magnetic anomalies associated with midocean ridges indicates that sea floor spreading is active in the vicinity of these ridges ${ }^{1}$. Mid-ocean ridges are thought likely to be the sites of upwelling convection currents and oceanic trenches to be the sites of descending currents ${ }^{2}$. Most trenches are associated with intense seismic activity $^{3-6}$. The hypocentres of earthquakes occur along almost planar zones (Benioff zones) which may be the result of movement of the sea floor under continents or island arcs. Seismic refraction studies of oceanic trenches, however, indicate that the sediments within the trenches are essentially undeformed and that there is no large accumulation of deformed sediments with a low seismic velocity associated with these trenches ${ }^{7-10}$. The absence of deformed low velocity sediments has been cited as evidence that the sea floor is not descending in the vicinity of these trenches ${ }^{7,8,10}$. Scholl et al. ${ }^{10}$ assume that deformed pelagic sediments would be expected within the trenches if the sea floor is actively underthrusting a continent or island arc. The centre of the Benioff zone, however, typically intersects the ocean floor landward of the axes of oceanic trenches ${ }^{4-6}$. This indicates that downward movement of the scdiments occurs landward of the axes of the trenches rather than directly under the axes of the trenches.

It seems likely that the pelagic sediments and turbidites deposited in trenches would be folded, faulted and thickened as they are carried beneath a continent or island arc (Fig. 1). This would lead to dewatering and

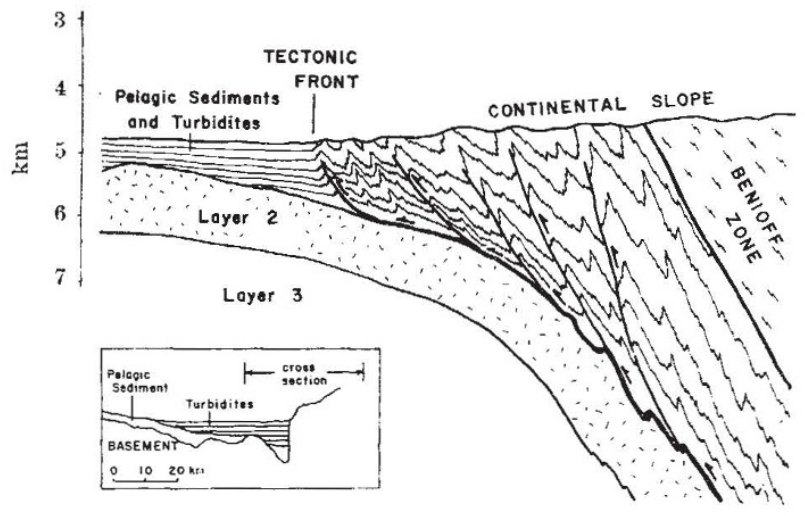

Fig. 1. Hypothetical cross-section through the Peru-Chile trench at approximately $36^{\circ} \mathrm{S}$. Sediment thickness from Scholl et al..$^{10}$ and thickness of layer 2 from Fisher and Raitt ${ }^{12}$. Vertical exaggeration is Scholl et al..$^{10}$ showing the location of the cross-section (vertical exaggeration is approximately $11: 1$ ). perhaps even low grade metamorphism of the sediments converting them into shale, graywacke, slate and metagraywacke. Landward of many trenches, a thin layer of low velocity sediments overlies a layer with a seismic velocity ranging from $4 \cdot 4-5 \cdot 0 \mathrm{~km} / \mathrm{s}$ (refs. 10-13). The layer with a velocity of $4 \cdot 4-5.0 \mathrm{~km} / \mathrm{s}$ may be composed of deformed sedimentary and metamorphic rocks which are in part equivalent to, and continuous with, the undeformed sediments in the adjacent trench. Balakrishna and Ramana ${ }^{14}$ report compressional wave velocities (measured in the laboratory) for shale ranging from $4 \cdot 2-5 \cdot 0 \mathrm{~km} / \mathrm{s}$, for slate ranging from $4 \cdot 2-5 \cdot 6 \mathrm{~km} / \mathrm{s}$ and for sandstone ranging from $4 \cdot 1-6 \cdot 2 \mathrm{~km} / \mathrm{s}$.

Seismic reflexion profiling of the Peru-Chile trench by Scholl et al. ${ }^{10}$ shows that there is a very sharp contact between the undeformed sediments within the trench and the higher seismic velocity layer which underlies the lower part of the continental slope. If the hypothesis proposed here is correct, this would indicate that the transition from undeformed sediments to deformed sedimentary and metamorphic rocks is rather abrupt. This contact may be a tectonic form similar to tho Allegheny front in the Appalachian Mountains ${ }^{15}$. Seismic reflexion profiling of the Allegheny front in Pennsylvania indicates that the transition from relatively undeformed Palaeozoic sedimentary rocks to highly deformed sedimentary rocks occurs in less than a quarter of a mile (R. A. Radulski, personal communication). Significantly, no reflexions were received from the steeply dipping beds east of the front. A possible reason that no reflexions have been reccived from the sedimentary rocks which underlie the lower part of the continental slope in areas such as east of the Peru-Chile trench may be that, as a result of folding, these beds are dipping too steeply to produce reflexions, or that they lack coherent reflectors. The lack of deformation of the sediments within the trench itself may simply indicute that the sediments are not capable of transmitting a compressive stress for large distances.

It is proposed that the reason for the absence of large thicknesses of deformed sediment associated with oceanic trenches is that these sediments have been thickened and converted into sedimentary and metamorphic rocks underlying the continental slope as a result of deformation along Benioff zones. If this is so, the absence of deformed sediments associated with oceanic trenches is not a valid argument against movement of the sea floor under continents and island ares in the ricinity of these trenches.

Cart K. Seyfert

Department of Geosciences,

Buffalo State University College,

Buffalo, New York.

Received January 28, 1969.

1 Heirtzler, J. R., Dickinson, G. O., Herron, E. M., Pitman, III, W. C., and Le Pichon, X., J. Geophys. Res., 73, 2119 (1968).

${ }^{2}$ Isacks, B., Oliver, J., and Sykes, I. R., J. Geophys. Res., 73, 5855 (1968).

${ }^{3}$ Tobin, D. G., and Sykes, L. R., J. Geophys. Res., 71, 1659 (1968).

4 Katsumata, M., J. Seismol. Soc. Japan, 20, 1 (1967).

${ }^{5}$ Sykes, L. R., J. Geophys. Res., 71, 2981 (1966).

${ }^{6}$ Harrington, H. J., in Polar Wandering and Continental Drift (edit. by Munyan, A. C.), 55 (Amer. Assoc. Petrol. Geol., Tulsa, Oklahoma, 1963).

'Ross, 1). A., and Shor, G. G., J. Geophys. Res., "70, 5551 (1965).

${ }^{8}$ Ewing, M., Ludwig, W. J., and Ewing, J. I., J. Geophys. Res., 70, 4593 $(1965)$.

' Ludwig, W. J., Ewing, J. I., Ewing, M., Murachi, S., Den, N., Asano, S., Hotta, H., Hayakawa, M., Asanuma, 'T., Ichikawa, K., and Noguchi, 1., J. Geophys. Res., 71, 2121 (1966).

in Scholl, D. W., Von Huene, R., and Ridlon, J. B., Srience, 159, 869 (1968).

${ }^{11}$ Shor, G. G., and Fisher, R. L., Geol. Soc. Amer., 72, 721 (1961).

12 Fisher, R. L., and Raitt, R. W., Deep-Sea Res., 9, 423 (1962).

${ }^{13}$ Fisher, R. L., and Hess, H. H., in The Sea (edit. by Hill, M. N.), 3,411 (Interscience, 1963).

14 Balakrishna, S., and Ramana, Y. V., in The Crust and Upper Mantle of the Pacific Area (edit. by Knopoff, , L., Drake, C. L., and Hart, P. J.), 489 (Amer. Geophys. Monog., 12, 1968).

is King, P. B., in The Evolution of North America (Princeton Unir. Prcss. Princeton, New Jersey, 1959). 